\title{
Isolation and molecular characterization of non tuberculosis mycobacteria from skin positive reactors and pathological lesions of cattle at Bako, Western Ethiopia
}

\author{
Temesgen Ayana ${ }^{1}$, Ketema Tafess ${ }^{2 \star}$, Gezahegne Mamo $^{3}$, Tesfaye Sisay Tessema ${ }^{3}$ and \\ Gobena Ameni ${ }^{4}$
}

\author{
${ }^{1}$ Department of Veterinary Laboratory Technology, Ambo University, P. O. Box 19, Ambo, Ethiopia. \\ ${ }^{2}$ Department of Biomedical Science, School of Health, Adama Science and Technology University, P. O. Box 04, Asella, \\ Ethiopia. \\ ${ }^{3}$ School of Veterinary Medicine, Addis Ababa University, P. O. Box 34, Debre Zeit, Ethiopia. \\ ${ }^{4}$ Aklilu Lemma Institute of Pathobiology, Addis Ababa University, P. O. Box 1176, Addis Ababa, Ethiopia.
}

Accepted 26 April, 2013

\begin{abstract}
A cross-sectional study was conducted on 858 cattle (371 recruited from Bako Agricultural Research Center, BARC and 487 from Bako municipal abattoir) from October 2009 to April 2010 to isolate and characterize Mycobacterial species from Skin positive reactors and pathological lesion positive cattle. To this effect, comparative intradermal tuberculin (CIDT) test, post mortem examination, bacteriological culturing, and genus typing using multiplex polymerase chain reaction (PCR) were applied. On the basis of CIDT, prevalence of positive reactors was $1.3 \%(95 \% \mathrm{Cl}: 0.15 ; 2.45)$ at the cut-off point of $\geq 4 \mathrm{~mm}$ following the recommendation of the World Organisation for Animal Health (OIE), and 9.0\% (95\% Cl: 6.0; 12.0) following the recently suggested cut-off of $>2 \mathrm{~mm}$. Apart from sex $(P=0.047)$, there was no association between host related risk factors and positive reactors upon univariate analysis. However, animals in the age category of 2 to 5 years, those with medium body condition score and cattle born on farm were at high relative risk of infection than the other categories. Lesion positivity in slaughtered cattle was $9.3 \%(95 \% \mathrm{Cl}: 6.3 ; 11.8)$. Lesions were more frequent and severe in the mesenteric $(60.9 \%)$, retropharyngeal (17.4\%), and bronchial (17.4\%) lymph nodes of slaughtered cattle. Culture positivity in suspicious tissues was $32.6 \%(29 / 89)$ out of which $69 \%$ (20 of 29) was confirmed to be acid-fast bacilli (AFB) on Ziehl Neelsen staining. Further characterisation of these isolates using genus typing (multiplex polymerase chain reaction) revealed that all of the isolates were members of the nontuberculous mycobacteria (NTM). The isolation of NTM from tubercle lesions underlines their roles in causing lesions, which are similar with lesions caused by Mycobacterium bovis. Therefore, further investigations to identify the specific species, the source of infections, transmission route and the pathogencity of NTM in specific host is recommended.
\end{abstract}

Key words: Bovine tuberculosis, non-tuberculous mycobacteria, grazing cattle, genus typing, Ethiopia.

\section{INTRODUCTION}

Bovine Tuberculosis (BTB) is a chronic infectious disease characterised by progressive development of granulomatous lesions or tubercles in the lung tissue, lymph nodes, or other organs of infected animals. 
Mycobacterium bovis (M. bovis), the causative agent of BTB, together with other highly related bacteria, forms a complex, the M. tuberculosis complex (MTC), a group of genetically very closely related (but distinct) mycobacteria (Imaeda, 1995). The MTC comprises seven members consisting of $M$. bovis, Mycobacterium tuberculosis, Mycobacterium africanum, Mycobacterium microti, Mycobacterium canetti Mycobacterium caprae, and Mycobacterium pinnipedii (Aranaz et al., 2003; Cousins et al., 2003; Smith et al., 2006). Among MTC, M. bovis has a wide range of target organs (lungs, gastrointestinal tract, mammary gland, kidney and reproductive organs) as well as mammalian hosts (wild animals, domestic animals and humans) (Phillips et al., 2002; Rupp et al., 2007).

Infection of cattle with $M$. bovis constitutes a human health hazard and economic implications in terms of trade restrictions and productivity losses (Phillips et al., 2002; Villarreal-Ramos et al., 2003). In low-income countries, particularly in Africa, the epidemiology and public health significance of BTB is largely unknown for politico-economic reasons, including the high costs of a sustainable testing programme, social unrest due to political instability and ethnic wars, resulting in the displacement of large numbers of human and animal populations, scarcity of veterinary expertise and communication networks. In addition, there are few or no laboratories that are capable of isolating and characterising mycobacteria from animal and human beings (Ayele et al., 2004).

In Ethiopia, the endemic nature of BTB in cattle has long been reported (Hailemariam, 1975). Most of the BTB surveys carried out in Ethiopia have been based on tuberculin skin testing and post mortem inspection of carcasses of slaughter animals in a particular locality. These limited and fragmented surveys show that the prevalence of BTB ranges from less than 1 to $50 \%$ depending on the production systems under which cattle are kept (Ameni et al., 2006, 2010; Berg et al., 2009; Tschopp et al., 2010a). Most of these studies did not involve the identification and characterisation of the causative agent. As a result, although the primary cause of BTB is assumed to be $M$. bovis, the scenario could be different in grazing cattle. In the present study, skin testing, pathological and bacteriological examinations and molecular characterisation of the isolates were used to establish the etiologic agent of tuberculosis-like lesions in grazing cattle.

\section{MATERIALS AND METHODS}

\section{Study site}

The study was conducted at Bako Agricultural Research Center(BARC) and Bako Municipal Abattoir, which are located in and around Bako town. Bako town is the center of Bako-Tibe district in Oromia National Regional State of Ethiopia. The town is located $250 \mathrm{~km}$ in the west of Addis Ababa, the capital of Ethiopia, at an altitude of $1650 \mathrm{~m}$ above sea level on $37^{\circ} 09^{\prime} \mathrm{E}$ and $9^{\circ} 06^{\prime} \mathrm{N}$. The town has hot and humid climate with average relative humidity of $60 \%$. It gets a bimodal pattern of rainfall with the main rainy season extending from June to September and a short rainy season that extends from March to May with an average annual rainfall of $1300 \mathrm{~mm}$. Mean monthly maximum and minimum temperatures are about 28 and $14^{\circ} \mathrm{C}$, respectively, with an average monthly temperature of $21^{\circ} \mathrm{C}$. The mean daily minimum and maximum temperatures are 9.4 and $31.1^{\circ} \mathrm{C}$, respectively (Gebregziabher and Mulugeta, 2006).

\section{Study animals and management}

The study cattle were recruited from Bako Agricultural Research Center (BARC) farm and from cattle kept by the traditional mixed crop-livestock farming communities inhabiting around Bako. For the CIDT test, all the apparently healthy cattle above six months of age from the research farm were used. Among the 371 tuberculin tested cattle, 253 (68.2\%) were Horro breed and 118 (31.8\%) were crossbred (Horro x Holstein) cattle. Horro cattle are described as an intermediate Sanga-Zebu type and are dominant cattle breed in western Ethiopia (Alberro and Hailemariam, 1982). The study cattle from the research farm were managed by semi-intensive production system. They were allowed to graze on natural pasture (in herds of 30 to 40 cattle) during the day for $8 \mathrm{~h}$. Thereafter, they were housed (in herds) in a barn with concrete floor and corrugated iron roof. The barn was cleaned daily and disinfected with $5 \%$ formalin at monthly interval. All animals were routinely monitored for any health problem and those above six months of age were annually vaccinated against Blackleg, Anthrax, Bovine Pasteurellosis, Lumpy Skin Disease (LSD) and Foot and Mouth disease (FMD). All the animals were de-wormed with anthelmintics and sprayed with acaricide regularly depending on the degree of parasite infestation and season of the year.

For Abattoir based survey, cattle slaughtered at Bako municipal abattoir were used. The slaughtered animals were purchased from local livestock markets by butchers and were brought to the abattoir for slaughter. All the slaughtered animals were indigenous Horro cattle managed under integrated extensive production system where cattle are kept primarily for draught power.

\section{Study design and sampling}

A cross-sectional study design with census sampling method was applied both in the research farm and Abattoir. Using this design, 371 cattle were recruited from the research farm and 487 were sampled from the Abattoir during the four months study period.

\section{Comparative intradermal tuberculin (CIDT) test}

While testing the study cattle by CIDT, body condition of each of the study animal was scored using the established guidelines for body condition scoring (Nicholson and Butterworth, 1986). For the CIDT test, two sites on the right side of the mid-neck, $12 \mathrm{~cm}$ apart in a horizontal line were shaved and the initial skin thicknesses were measured with calipers. One site was injected intradermally with an aliquot of $0.1 \mathrm{ml}$ containing $2500 \mathrm{IU} / \mathrm{ml}$ bovine purified protein derivative (PPD) (Veterinary Laboratories Agency, Addlestone, Surrey KT15 3NB, UK).Similarly, $0.1 \mathrm{ml}$ of $2500 \mathrm{IU} / \mathrm{ml}$ avian PPD (Veterinary Laboratories Agency, Addlestone, Surrey KT15 3NB, UK) was injected into the second site. After $72 \mathrm{~h}$, the skin thicknesses at the injection sites were measured and registered. Test results were interpreted according to the recommendations of the Office International des Epizootics (OIE, 2009) for all animals and the recommendation for local animals (Ameni et al., 2008). 


\section{Post mortem examination and pathology scoring}

The lungs, lymph nodes and liver were removed by the investigator for the investigation of tubercle lesions. Each of the seven lobes of the two lungs were thoroughly inspected and palpated for any suspicious gross tuberculous lesions. Each lobe was sectioned into $2 \mathrm{~cm}$ thick slices to facilitate the detection of lesions. Similarly, mandibular, retropharyngeal, cranial and caudal mediastinal, left and right bronchial, hepatic, and mesenteric lymph nodes were sliced into thin sections and inspected for the presence of visible lesions (FAO, 2000). When gross lesions suggestive of BTB were found in any of the tissues, the animal was classified as having lesions. Furthermore, the severity of the gross lesions was scored by the semi-quantitative procedures described earlier (Ameni et al., 2007a, Vordermeier et al., 2002). Briefly, lesions in the lobes of the lungs were scored separately as follows: $0=$ no visible lesions; $1=$ no gross lesions but lesions apparent on slicing of the lobe; $2=$ fewer than five gross lesions; 3 = more than five gross lesions; $4=$ gross coalescing lesions. The scores for the individual lobes were added up to calculate the lung score. Similarly, the severity of gross lesions in individual lymph nodes was scored as follows: $0=$ no gross lesions; 1 = small lesion at one focus (just starting); 2 = small lesions at more than one focus; $3=$ extensive necrosis.

\section{Isolation of mycobacteria}

Lesions suspicious of tuberculosis upon postmortem examination were collected and placed in a $50 \mathrm{ml}$ tubes with screw caps containing $5 \mathrm{ml}$ of sterile $0.9 \%$ saline. A total of 89 specimens were collected from 46 cattle and transported in ice box to Aklilu Lemma Institute of Pathobiology (ALIPB, Addis Ababa). In the laboratory, the specimens were sectioned using sterile blades and then homogenised with a mortar and pestle. The homogenate was decontaminated by adding an equal volume of $4 \% \mathrm{NaOH}$ by centrifugation at $3,000 \mathrm{rpm}$ for $15 \mathrm{~min}$. The supernatant was discarded, and the sediment was neutralised by $1 \%(0.1 \mathrm{~N}) \mathrm{HCl}$ using phenol red as an indicator. Neutralisation was achieved when the color of the solution changed from purple to yellow (OIE, 2009). Next, $0.1 \mathrm{ml}$ of suspension from each sample was spread onto a slant of Lowenstein-Jensen (LJ) medium. Duplicate slants were used, one enriched with sodium pyruvate and the other enriched with glycerol. Cultures were incubated aerobically at $37^{\circ} \mathrm{C}$ for about 10 weeks with weekly observation for growth of colonies. Cultures were considered negative if no visible growth was detected after 10 weeks of incubation. In the presence of visible growth of colonies, microscopic examination of cultures using the Ziehl-Neelsen (ZN) staining method was performed to select acid-fast bacilli (AFB) positive isolates.

\section{Molecular typing}

AFB positive isolates were heat-killed by mixing approximately 2 loopfuls of colonies in $200 \mu \mathrm{l}$ distilled $\mathrm{H}_{2} \mathrm{O}$ followed by incubation at $80^{\circ} \mathrm{C}$ for $45 \mathrm{~min}$. Thereafter, Multiplex polymerase chain reaction (m-PCR) was used to confirm the presence of genus Mycobacterium in the isolate and to differentiate $M$. tuberculosis complex from $M$. avium complex, and other mycobacterial species following the standard operating procedure developed previously (VLA, 2005). The PCR targets the sequence of the genus Mycobacterium within the 16S rRNA gene (G1, G2), sequences within the hyper-variable region of 16S rRNA that is known to be specific to $M$. avium (MYCAV-R), and the MTB70 gene specific for $M$. tuberculosis complex. Heat killed AFB positive samples were used as source of DNA template. The reaction was carried out using Thermal Cycler (Applied Biosystems, GeneAMP 9700). Each PCR tube consisted of $5.2 \mu \mathrm{l} \mathrm{H} \mathrm{H}_{2} \mathrm{O}, 8 \mu \mathrm{l} \mathrm{HotStarTaqMasterMix,} 0.3 \mu \mathrm{l}$ of each of the primers, $5 \mu \mathrm{l}$ of DNA templates of samples or controls making the total volume $20 \mu \mathrm{l}$. M. avium, and 2122/97 (M. bovis strain) were used as positive controls while $\mathrm{H}_{2} \mathrm{O}$ (Qiagen), was used as a negative control. The mixture was heated for $15 \mathrm{~min}$ at $95^{\circ} \mathrm{C}$, followed by 35 cycles of $1 \mathrm{~min}$ denaturation at $95^{\circ} \mathrm{C}, 1 \mathrm{~min}$ annealing at $61^{\circ} \mathrm{C}$, and 1 min extension at $72^{\circ} \mathrm{C}$; and final extension was done for $10 \mathrm{~min}$ at $72^{\circ} \mathrm{C}$. The PCR product was electrophoresed in 1\% agarose gel in $1 \mathrm{XTAE}$ running buffer. Ethidium bromide at a ratio of $1: 200000$ in 1\% agarose gel, $100 \mathrm{bp}$ DNA ladder, and orange $6 x$ loading dye were used during gel electrophoresis. The gel was visualised in Multi-imageTM light cabinet using Alpha Innotech version 1.2.0.1 (Alpha Innotech Corporation). All members of the Genus Mycobacterium produced a band of $1030 \mathrm{bp}, M$. avium or subspecies such as M. avium subspecies paratuberculosis produces a band of $180 \mathrm{bp}$, while members of $M$. tuberculosis complex produce a band with $372 \mathrm{bp}$.

\section{Data management and analysis}

The data were coded and analysed using SPSS for Windows (Version 14.0; Statistical Package for Social Sciences Inc, Chicago, Illinois, USA). Proportions were used to summarise categorical exposure and outcome measures. Similarly, descriptive statistics such as mean and standard error of the mean were used to summarise pathology scores. Univariate and multivariate logistic regression analysis were conducted to examine the relationship between the outcome variable and selected animal risk factors. Odds Ratio (OR) with 95\% confidence intervals ( $\mathrm{Cl}$ ) was used to assess the level of association of prevalence to the different host factors. A statistically significant association between the different variables were said to exist if the estimated $P$-value is less than $0.05(\mathrm{P}<0.05)$ and the 95\% confidence interval $(\mathrm{Cl})$ for OR doesn't include 1.0 .

\section{RESULTS}

\section{Prevalence of bovine tuberculosis}

An apparent positive reactor at cut-off point of $\geq 4 \mathrm{~mm}$ following the recommendation of OIE was $1.3 \%(95 \% \mathrm{Cl}$ : $0.15 ; 2.45)$. On the other hand, the prevalence of nonspecific reactors was $3.5 \%(95 \% \mathrm{Cl}: 1.6 ; 5.40)$. On the basis of the newly defined cut-off value of $\geq 2 \mathrm{~mm}$ (Ameni et al., 2008), the apparent positive reactors was increased to $9.0 \%(95 \% \mathrm{Cl}: 6.0 ; 12.0)$. Apart from sex $(\mathrm{P}=0.047)$, there was no association between breed, age, body condition, origin, pregnancy, and parity and positive reactors upon univariate analysis. However, animals in the age category of 2-5 years, those with medium body condition score and cattle born on farm were at high risk of infection than the other categories (Table 1).

Lesion prevalence was calculated for the 5 tuberculin reactor cattle from research farm and 487 slaughter cattle recruited from Bako municipal abattoir. Overall lesion prevalence was $9.3 \%(95 \% \mathrm{Cl}$ : $6.3 ; 11.84)$. Suspected TB lesions were observed in different tissues of the study animals (Table 2). There was a significant difference $\left(X^{2}=91.174 ; P=0.000\right)$ in occurrence of lesions in different tissues of the study animals. Of the five skin test positive cattle killed for post mortem examination, tubercle lesions were detected in $3(60 \%)$ of the animals for which lesion 
Table 1. Logistic regression analysis of host related risk factors with tuberculin test positivity using the $>2 \mathrm{~mm}$ cut-off point.

\begin{tabular}{lcccc}
\hline Variables & Number examined & Number positive (\%) & $\begin{array}{c}\text { Crude odds ratio } \\
(95 \% \text { Cl) }\end{array}$ & Adjusted odds ratio (95\% Cl) \\
\hline Sex & 83 & $12(14.5)$ & & \\
Male & 288 & $21(7.3)$ & $0.46(0.22-0.99)$ & $0.48(0.21-1.11)$ \\
Female & & & & \\
Age group & 87 & $7(8.0)$ & & \\
$\leq 2$ & 109 & $17(15.6)$ & $2.11(0.83-5.35)$ & $0.79(0.23-2.63)$ \\
$2-5$ & 72 & $4(5.6)$ & $0.67(0.19-2.39)$ & $0.17(0.03-0.94)$ \\
$5-8$ & 48 & $3(6.3)$ & $0.76(0.19-3.09)$ & $0.37(0.07-1.93)$ \\
$8-12$ & 55 & $2(3.6)$ & $0.43(0.08-2.15)$ & $0.11(0.01-0.86)$ \\
$>12$ & & & & \\
Breed & 253 & $27(10.7)$ & & \\
Local & 118 & $6(5.1)$ & $0.45(0.18-1.12)$ & $0.27(0.08-0.89)$ \\
Cross & & & & \\
Body condition & 36 & $2(5.6)$ & & $1.73(0.35-8.61)$ \\
Thin & 299 & $29(9.7)$ & $1.83(0.41-7.99)$ & $1.95(0.21-18.30)$ \\
Medium & 36 & $2(5.6)$ & $1(0.13-7.51)$ & \\
Good & & & \\
Origin & 120 & $10(8.3)$ & & \\
Purchased & 251 & $23(9.2)$ & $1.11(0.5104-2.41)$ & $0.52(0.18-1.49)$ \\
Born on farm & & & \\
\hline
\end{tabular}

Table 2. Proportion and severity of lesioned tissues of bovine tuberculosis in cattle slaughtered at Bako municipal abattoir, Western Oromia, Ethiopia.

\begin{tabular}{lccc}
\hline Tissues & Number examined & Number positive (\%) & $\begin{array}{c}\text { Lesion severity } \\
\text { (Mean } \pm \text { SEM) }\end{array}$ \\
\hline Lung lobes & 46 & $1(2.2)$ & \\
Left apical & 46 & $2(4.3)$ & $0.04 \pm 0.04$ \\
Left cardiac & 46 & $2(4.3)$ & $0.13 \pm 0.09$ \\
Left diaphragmatic & 46 & $1(2.2)$ & $0.15 \pm 0.11$ \\
Right cardiac & 46 & $1(2.3)$ & $0.04 \pm 0.04$ \\
Right accessory & 46 & $2(4.3)$ & $0.04 \pm 0.04$ \\
Right diaphragmatic & & & $0.17 \pm 0.12$ \\
& & & \\
Lymph nodes & & & \\
Mandibular & 46 & $1(2.2)$ & $0.02 \pm 0.02$ \\
Retropharyngeal & 46 & $8(17.4)$ & $0.33 \pm 0.12$ \\
Left bronchial & 46 & $8(17.4)$ & $0.28 \pm 0.10$ \\
Cranial mediastinal & 46 & $3(6.5)$ & $0.07 \pm 0.03$ \\
Caudal mediastinal & 46 & $4(8.7)$ & $0.13 \pm 0.07$ \\
Hepatic & 46 & $6(13.0)$ & $0.22 \pm 0.09$ \\
Mesenteric & & & \\
& 46 & $28(60.9)$ & $1.11 \pm 0.15$ \\
Liver & 46 & $4(8.7)$ & $0.15 \pm 0.08$ \\
\hline
\end{tabular}




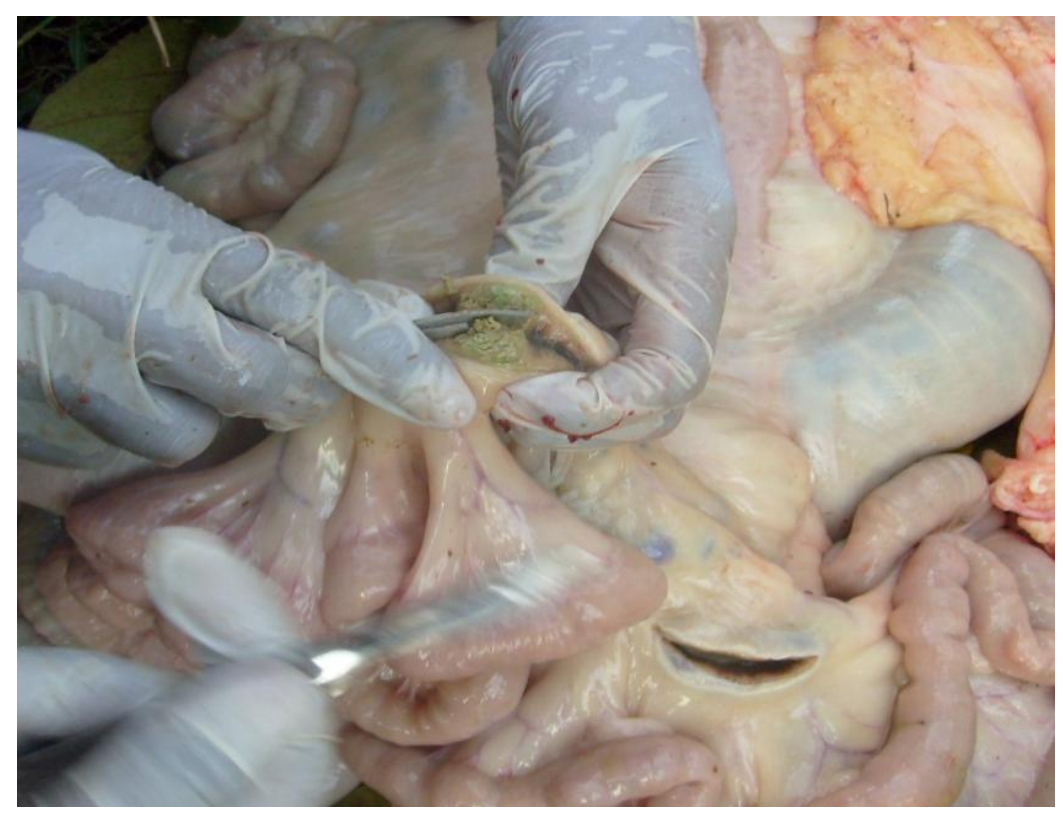

Figure 1. Tuberculous lesion detected in mesenteric lymph node of one of the tuberculin skin test positive cattle at Bako Agricultural Research Centre.

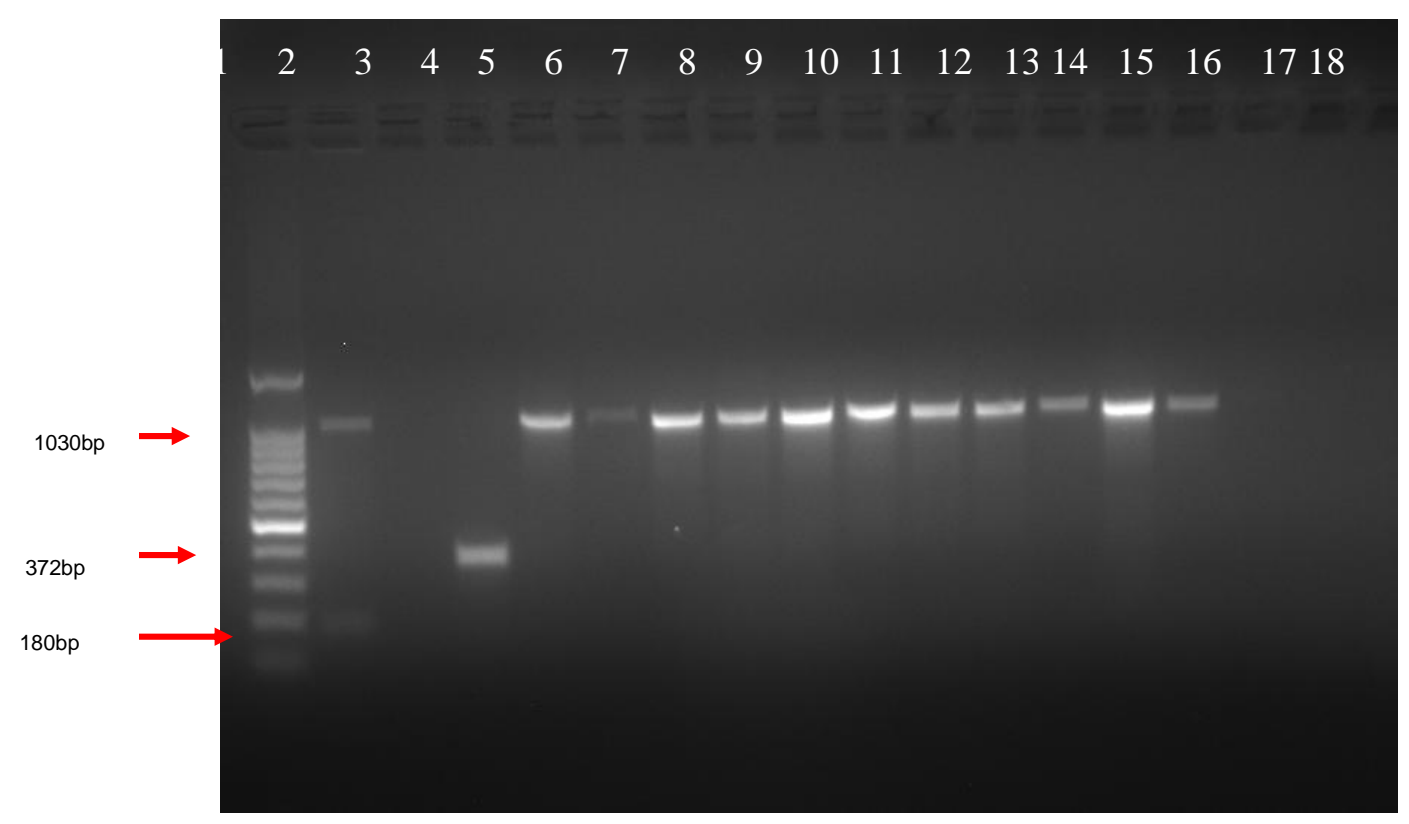

Figure 2. Gel electrophoresis separation of PCR products by multiplex PCR genus typing of mycobacteria isolated from cattle of western Ethiopia. Lane 1= 100 bp Ladder; Lane 2=M. avium complex (positive control); Lane 3= Qiagen $\mathrm{H}_{2} \mathrm{O}$ (negative control); Lane 4= M. tuberculosis complex (positive control); Lane 5-18 were isolates from individual cattle with suspected tuberculous lesions; Lane 5-15 were positive for genus Mycobacterium; Lane 16-18 were negative for genus Mycobacterium.

distribution and severity was established. All the three tuberculin reactor cattle had lesions in mesenteric lymph node (Figures 1 and 2); $66.7 \%$ had lesions in retropharyngeal and cranial mediastinal lymph nodes. Lung lesion was observed in only one of the tuberculin reactor cattle.

On the other hand, $8.83 \%$ (43 of 487 ) of slaughter cattle from Bako municipal abattoir had tubercle lesions in one or more tissues/organs of the body. As indicated in Table 2, mesenteric lymph node was found to be the 
most severely affected tissue (mean pathology score $\pm S E M, 1.11 \pm 0.15)$. The characteristic lesions observed upon gross pathological examination in the mesenteric and other lymph nodes had distinct enlargement and upon sectioning, the lymph nodes had greenish confluent caseous necrosis (Figure 1) with some calcification of the necrotized tissue, different from the usual yellowish or grey white caseous necrosis which is commonly observed in lesions caused by $M$. bovis infection.

\section{Isolation of mycobacteria}

Of the 89 tissue specimens cultured on primary culture media, 29 specimens showed growth, constituting a culture positivity of $32.6 \%$. Colonies of culture positive isolates were processed to demonstrate acid-fast bacilli (AFB) under a microscope. Accordingly, 69\% (20 of 29) isolates showed acid-fast bacilli on ZN staining.

\section{Molecular typing}

AFB positive samples were further characterised by Mycobacterium genus typing. Multiplex polymerase chain reaction (m-PCR) analysis revealed the presence of the genus Mycobacterium in $80 \%$ (16 of 20) of the isolates of which 11 isolates were depicted by Figure 2. None of the isolates belonged to the $M$. tuberculosis complex. However, all the isolates including those from BTB reactors were identified as NTM.

\section{DISCUSSION}

This study provides the first data on tuberculosis in the study area and study animals (Horro breed and their crosses). The overall prevalence of $1.3 \%$ ( $\geq 4 \mathrm{~mm}$ cut-off) found in this study is similar with the prevalence reported by other workers in the traditional farms of Ethiopia in zebu breed (Shihun, 2008; Tschopp et al., 2010a, 2010b). Moreover, in Uganda and Tanzania, different researchers reported comparable animal prevalence in indigenous cattle in different districts (Cleaveland et al., 2007; Inangolet et al., 2008; Oloya et al., 2006; Shirima et al., 2003). However, higher prevalence was recorded in intensive farms in Ethiopia (Ameni et al., 2010; Regassa et al., 2010).

The low positive reactors in the present study could, among others, be due to the fact that the study animals were kept in small herds and widely exercise free grazing in the field, which minimises the transmission of mycobacteria contrary to the intensive farms which favors the spread of mycobacteria because of confinement and overcrowding. Moreover, all the cattle enrolled into the present study were zebu breed, and their crosses which are relatively resistant to tuberculosis (Ameni et al., 2006; Radostits et al., 2000).

Our study shows apparent prevalence of $8.9 \%$ using a cut-off for skin test reaction of $\geq 2 \mathrm{~mm}$ as suggested by Ameni et al. (2008), who stated that maximum sensitivity can be achieved in central Ethiopia using a $\geq 2 \mathrm{~mm}$ cut-off without affecting specificity. A similar finding was reported by Gumi et al. (2011). However, a lower prevalence were reported by other researchers (Tschopp et al., 2010a, 2010b; 2010c; Tschopp et al., 2009) from different areas of Ethiopia. The use of appropriate cut-off point of a diagnostic test is critically important in disease surveillance and hence disease control and eradication.

In the present study, detailed post mortem examination of carcasses revealed an apparent lesion prevalence of $9.3 \%$ which is in agreement with the report by Biffa and others (Biffa et al., 2009). In contrast, it is higher than the some reports from Ethiopia (Ameni et al., 2010, Berg et al., 2009; Regassa et al., 2010) although it is lower than other reports from Ethiopia and Tanzania (Cleaveland et al., 2007; Mamo et al., 2011). The frequency and severity of tubercle lesion in slaughter cattle was higher in the mesenteric lymph node than the thoracic lymph nodes. Similarly, few studies reported higher lesion prevalence in alimentary tract of animals managed under similar settings (Cleaveland et al., 2007; Mamo et al., 2011). The localisation of the majority of tuberculosis lesions in mesenteric lymph nodes in free grazing cattle indicates that the ingestion route might be the principal route of transmission (Radostits et al., 2000; Whipple et al., 1996). In a comparative BTB study in grazing and housed cattle, Ameni and others observed a significant difference in lesion distribution between animals farmed intensively and those kept on pasture (Ameni et al., 2007b). Accordingly, digestive tract lesions predominated in animals kept on pasture whereas animals in intensive farms were presented with lesions predominantly in the respiratory tract.

Molecular characterisations of AFB positive isolates using $\mathrm{m}$-PCR revealed that all of the isolates were NTM. The characterisation of these NTM from traditionally free grazing cattle with gross tuberculous-like lesions might indicate the role of NTM in epidemiology of animal tuberculosis in the study area. However, a definitive conclusion about the role of NTM in the epidemiology of animal tuberculosis in the whole breeding region of western Ethiopia is not possible because of the small number of animals examined in this study. On the other hand, the characterisation of NTM from tuberculous tissues of cattle from the research farm and abattoir could indicate their role in hindering the detection of TB in cattle in the area and the possible underestimation of the prevalence of TB in studies that depend on tuberculin testing. To this effect, the low prevalence of TB in cattle from the research farm in our study might be due to the effect of NTM.

The characterisation of NTM from TB reactors in our 
study may be due to mixed-infection of the animals with $M$. bovis and NTM. As NTM infection is widespread in grazing cattle in the area, tuberculin reactor cattle from the research farm $(80 \%$ of reactor animals from the research farm were those purchased from local market and introduced into the herd) may be infected with both NTM and $M$. bovis. It is known that NTM tends to outgrow the slowly growing $M$. bovis in culture. In contrary, animals that showed positive result for both tuberculin test and NTM could possibly be due to false positive reaction to $M$. bovis as a result of cross-reaction with the antigens contained in the NTM.

In the present study, we demonstrated a high prevalence of environmental mycobacteria in grazing cattle. Previous studies in Ethiopia and Tanzania revealed the association of NTM with granulomatous lesions in cattle and humans (Berg et al., 2009). An extensive study on Ethiopian cattle confirmed that about one third of the isolates from tuberculous lesions were NTM (Berg et al., 2009; Shihun, 2008). Moreover, NTM were associated with tuberculous camel and wildlife populations in Ethiopia $(22,38)$.

Similar studies in Uganda and Chad reported the isolation of NTM strains from more than $40 \%$ of the animals with tuberculous lesions (Diguimbaye-Djaïbe et al., 2006; Oloya et al., 2006). In the present study, the NTM isolates were not characterised to the species and strain level due to lack of laboratory facilities particularly a sequencer to sequence the 16S rRNA locus (Han et al., 2002). It would have been very useful to compare our results with other works where NTM were isolated in the frame work of TB studies in other countries.

In our study, most of the NTM were isolated from mesenteric lymph nodes, suggesting the environmental exposure of the animals through ingestion with fodder or water. Moreover some of the NTM were isolated from bronchial and medisatinal lymph nodes, suggesting aerosol transmission. So far, there are no studies demonstrating the entry route and tissue tropism for NTM in domestic livestock, humans, and wildlife. In this study, the detection of majority of the lesions and NTM in mesenteric lymph nodes could be inherent to the NTM infection route and their tissue tropism as it is the case for digestive tract in Jones disease due to $M$. paratuberculosis.

Although $M$. bovis has been known to be the major cause of BTB in cattle, mycobacteria other than $M$. tuberculosis complex members were isolated from the suspicious lesions in the present study. The isolation of these NTM from tubercle lesions underlines their roles in causing lesions, which are milder as compared to the lesions caused by $M$. bovis. Further investigation for the identification of specific species, the source of infections, transmission route and their pathogencity in specific host is needed. Moreover, the role and public health significance of NTM in human population of the region should be investigated.

\section{ACKNOWLEDGEMENTS}

The School of Veterinary Medicine and Aklilu Lemma Institute of Pathobiology are appreciated for their financial and logistic supports.

\section{REFERENCES}

Alberro M, Hailemariam S (1982). The indigenous cattle of Ethiopia, Part I. World Anim. Rev. 41:2-11.

Ameni G, Aseffa A, Engers H, Young D, Gordon S, Hewinson G, Vordermeier M (2007a). High prevalence and increased severity of pathology of bovine tuberculosis in Holsteins compared to zebu breeds under field cattle husbandry in central Ethiopia. Clin. Vacc. Immunol. 14:1356-1361.

Ameni G, Aseffa A, Engers H, Young D, Hewinson G, Vordermeier M (2006). Cattle husbandry in Ethiopia is a predominant factor affecting the pathology of bovine tuberculosis and gamma interferon responses to mycobacterial antigens. Clin. Vacc. Immunol. 13:10301036.

Ameni G, Aseffa A, Sirak A, Engers H, Young D, Hewinson G, Vordermeier M, Gordon S (2007b). Effect of skin testing and segregation on the prevalence of bovine tuberculosis, and molecular typing of $M$. bovis, in Ethiopia. Vet. Rec. 161:782-786.

Ameni G, Desta F, Firdessa R (2010). Molecular typing of Mycobacterium bovis isolated from tuberculosis lesions of cattle in northeastern Ethiopia. Vet. Rec. 167:138-141.

Ameni G, Hewinson G, Aseffa A, Young D, Vordermeier M (2008). Appraisal of interpretation criteria for the comparative intradermal tuberculin test for diagnosis of tuberculosis in cattle in central Ethiopia. Clin. Vaccine Immunol. 8:1272-6.

Aranaz A, Cousins D, Mateos A, Dominguez L (2003). Elevation of Mycobacterium tuberculosis subsp. caprae Aranaz et al. 1999 to species rank as Mycobacterium caprae comb. nov. , sp. nov. Int. J. Syst. Evol. Microbiol. 53:1785-1789.

Ayele WY, Neill SD, Zinsstag J, Weiss MG, Pavlik I (2004). Bovine tuberculosis: An old disease but a new threat to Africa. Int. J. Tuberc. Lung Dis. 8:924-937.

Berg S, Firdessa R, Habtamu M, Gadisa E, Mengistu A, Yamuah L, Ameni G, Vordermeier M, Robertson BD, Smith NH, Engers $\mathrm{H}$, Young D, Hewinson RG, Aseffa A, Gordon SV (2009). The burden of mycobacterial disease in Ethiopian cattle: Implications for public health. PLoS One 4:e5068.

Biffa D, Inangole F, Oloya J, Asseged B, Badaso M, Yilkal A, Skjerve E (2009). Prevalence of bovine tuberculosis in Ethiopian slaughter cattle based on post mortem examination. Trop. Anim. Health Prod. 41:755-65.

Cleaveland S, Shaw DJ, Mfinaga SG, Shirima G, Kazwala RR, Eblate E, Sharp M (2007). Mycobacterium bovis in rural Tanzania: Risk factors for infection in cattle and human populations. Tuberculosis 87:30-43.

Cousins DV, Bastida R, Cataldi A, Quse V, Redrobe S, Dow S, Duignan P, Murray A, Dupont C, Ahmed N, Collins DM, Butler WR, Dawson D, Rodríguez $\mathrm{D}$, Loureiro J, Romano $\mathrm{Ml}$, Alito $\mathrm{A}$, Zumarraga $\mathrm{M}$, Bernardelli A (2003). Tuberculosis in seals caused by a novel member of Mycobacterium tuberculosis complex: Mycobacterium pinnipedii sp. nov. Int. J. Syst. Evol. Microbiol. 53:1305-1313.

Diguimbaye-Djaibé $C$, Vincent $V$, Schelling $E$, Hilty $M$, Ngandolo $R$, Mahamat HH, Pfyffer G, Baggi F, Tanner M, Zinsstag J (2006). Species identification of non-tuberculous Mycobacteria from humans and cattle of Chad. Schweiz. Arch. Tierheilkd. 148:251-256

FAO (2000). Manual on meat inspection for developing countries. FAO Animal Production and Health Paper 119, FAO, Rome, Italy.

Gebregziabher G, Mulugeta K (2006). Herd life and lifetime calf crop production in relation to age at first calving in indigenous and crossbred cows at Bako, Ethiopia. Eth. J. Anim. Prod. 6:55-65.

Gumi B, Schelling E, Firdessa R, Aseffa A, Tschopp R, Yamuah L, Young D, Zinsstag $J(2011)$. Prevalence of bovine tuberculosis in pastoral cattle herds in the Oromia region, southern Ethiopia. Trop. 
Anim. Health Prod. 43:1081-1087.

Hailemariam S (1975). A brief analysis of the activities of the meat inspection and quarantine division, Ministry of Agriculture (MOA), Addis Ababa, Ethiopia.

Han XY, Pham AS, Tarrand JJ, Sood PK, Luthra R (2002). Rapid and accurate identification of mycobacteria by sequencing hypervariable regions of the 16S ribosomal RNA gene. Am. J. Clin. Pathol. 118: 96801.

Imaeda T (1995). DNA relatedness among selected strains of $M$. tuberculosis, M. bovis, M. bovis BCG, M. mcroti and M. africanum. Int. J. Syst. Bacteriol. 3:147-150.

Inangolet FO, Demelash B, Oloya J, Opuda-Asibo J, Skjerve E (2008). A cross-sectional study of bovine tuberculosis in the transhumant and agro-pastoral cattle herds in the border areas of Katakwi and Moroto districts, Uganda. Trop. Anim. Health Prod. 40:501-508.

Mamo G, Bayleyegn G, Tessema TS, Legesse M, Medhin G, Bjune G., Abebe F, Ameni G (2011). Pathology of Camel Tuberculosis and Molecular characterization of Its Causative Agents in Pastoral Regions of Ethiopia. PLoS One 6(1):e15862.

Nicholson MJ, Butterworth MA (1986). A guide to condition scoring zebu cattle. International Livestock Center for Africa (ILCA), Addis Ababa, Ethiopia, pp. 72-74.

OIE (2009). Bovine Tuberculosis. Manual of diagnostic tests and vaccines for Terrestrial animals, Part 2 Section 2.3. Chapter 2.3.3. World Organisation for Animal Health, Paris.

Oloya J, Opuda-Asibo J, Djonne B, Muma JB, Matope G, Kazwala R, Skjerve E (2006). Response to tuberculin among Zebu cattle in the transhumance regions of Karamoja and Nakasongola district of Uganda. Trop. Anim. Health Prod. 38:275-283.

Phillips C, Foster W, Morris A, Teverson R (2002). Genetic and management factors that influences the susceptibility of cattle to Mycobacterium bovis infection. Anim. Health Res. Rev. 3:3-13.

Radostits OM, Gay CC, Blood DC, Hinchelift KW (2000). Disease caused by bacteria-Mycobacterium. In: Veterinary Medicine: A Text Book of Disease of Cattle, Sheep, Pig, Goat and Horses. $9^{\text {th }}$ ed., Harcourt publisher Ltd., London. pp. 909-918.

Regassa A, Tassew A, Amenu K, Megersa B, Abunna F, Mekibib B, Macrotty T Ameni $G$ (2010). A cross-sectional study on bovine tuberculosis in Hawassa town and its surroundings, Southern Ethiopia. Trop. Anim. Health Prod. 42:915-920.

Rupp R, Hernandez F, Mallard A (2007). Association of bovine Leukocyte antigen (BoLA)-DRB3.2 with immune response, mastitis, and production and type trait in Canadian Holstein. J. Dairy Sci. 90:1029-1038.
Shihun SB (2008). Bovine tuberculosis: Epidemiologic aspects and public health significance in and around Debre Birhan, Ethiopia. MSc thesis, Addis Ababa University, Faculty of Veterinary Medicine, Ethiopia.

Shirima GM, Kazwala RR, Kambarage DM (2003). Prevalence of bovine tuberculosis in cattle in different farming systems in the Eastern zone of Tanzania. Prev. Vet. Med. 57:167-172.

Smith NH, Gordon SV, de la Rua-Domenech R, Clifton-Hadley RS, Hewinson RG (2006). Bottlenecks and Broomsticks: The molecular evolution of Mycobacterium bovis. Nat. Rev. Microbiol. 4:670-681.

Tschopp R, Aseffa A, Schelling E, Berg S, Hailu E, Gadisa E, Habtamu M, Argaw K, Zinsstag J (2010a). Bovine Tuberculosis at the WildlifeLivestock-Human Interface in Hamer Woreda, South Omo, Southern Ethiopia. PLoS One 5(8):e12205.

Tschopp R, Berg S, Argaw K, Gadisa E, Habtamu M, Schelling E, Young D, Aseffa A, Zinsstag J (2010c). Bovine tuberculosis in Ethiopian wildlife. J. Wildlife Dis. 46:753-762.

Tschopp R, Schelling E, Hattendorf J, Aseffa A, Zinsstag J (2009). Risk factors of bovine tuberculosis in cattle in rural livestock production systems of Ethiopia. Prev. Vet. Med. 89:205-211.

Tschopp R, Schelling E, Hattendorf J, Young D, Aseffa A, Zinsstag J (2010b). Repeated cross-sectional skin testing for bovine tuberculosis in cattle kept in a traditional husbandry system in Ethiopia. Vet. Rec. 14:250-256.

Villarreal-Ramos B, McAulay M, Chance V, Martin M, Morgan J, Howard CJ (2003). Investigation of the role of CD8+ T cells in bovine tuberculosis in vivo. Infect. Immunol. 71:4297-4303.

VLA (2005). TB multiplex polymerase chain reaction. Standard operating procedure, Veterinary Laboratories Agency (VLA), Weybridge, pp. 2-18.

Vordermeier MH, Chambers MA, Cockle PJ, Whelan AO, Simmons J, Hewinson GR (2002). Correlation of ESAT-6-specific gamma interferon with pathology in cattle following Mycobacterium bovis BCG vaccination against experimental bovine tuberculosis. Infect. Immunol. 70:3026-3032.

Whipple DL, Bolin CA, Miller JM (1996). Distribution of lesion in cattle infected with Mycobacterium bovis. J. Vet. Diag. Invest. 8:351-354. 